\title{
A DESCRIPTIVE ANALYSIS OF ENGLISH INDONESIAN CODE SWITCHING SPOKEN BY THE TEACHER IN THE FIRST GRADE OF MTsN MODEL MAKASSAR
}

\author{
Nur Aliyah Nur \\ Fitriyani \\ English Education Department of UIN Alauddin Makassar
}

\begin{abstract}
The research aims to analyse the English Indonesia Code Switching Spoken by the Teacher in First Grade of MTsN Model Makassar. The principal issue into several subproblems or research questions such as 1) What are grammatical aspects of code switching in English Indonesian code switching spoken by the teacher in the first grade of MTsN Model Makassar?. 2) What are sosiolinguistic aspects of code switching in English Indonesian code switching spoken by the teacher in the first grade of MTsN Model Makassar?, and 3) What is the function of code switching in English Indonesian code switching spoken by the teacher in the first grade of MTsN Model Makassar?. The study was designed in the form of qualitative descriptive study. The subject in this study wasone of English teachers in the $7^{\text {th }}$ grade of MTsN Model Makassar who teaches the VII.11 class. The data were collected by using the methods of recording and writing on note of what teacher said in teaching learning process, then collected it and classified based on grammatical aspect of code switching, sociolinguistic aspect, and the function (phatic function) of code switching. A grammatical focuses on the structural aspect of code switching. While, a sociolinguistic approach is concerned with the role of social factors of code switching. The result of this research showed that the grammatical aspect of code switching are extrasentential/tag switching, intersentential switching, and intra word of code switching. Sociolinguistic aspects of code switching are situational and metaphorical switching. The function of code switching are referential function, directive function, phatic function and metalingustic function. But this thesis only focused on phatic function to clarify or emphasize a message. The achievement of this research can be used to make easier in teaching foreign language and can be used as additional source and also can develop code switching field in the next research.
\end{abstract}

KEYWORDS: Descriptive analysis, code switching

\section{A. INTRODUCTION}

language is a system of conventional vocal signs by means of the which. Human
as social creature, live in their community within language, culture, and also
tradition. The interaction can be done by understanding their language, people are able to share and convey their thougt and feeling to the others. Using language in social life is studied in sosiolinguistics. Holmes (1992:2) stated that sosiolinguistics is the study of relationship between language and society. Holmes also stated that sosiolingiustics is concerned with the relationship between language and the context in which it is used. Meanwhile social life has many variations of contexts and languages in interactions, so the 
fluency of communication will be influenced by social factor like what Holmes stated in his book, that some relate to the users of language of the participant and others relate to its user the social setting and function of the interaction. In this case who is talking to whom. The other factor is the setting or social context. And Then the purpose of communication.

Now, there are many people use more than one language in communication with people arround them, in this case especially in education as happened in the process of learning English in the classroom. Most of the English teacher in Indonesia still used two language in their conversation with their students when teaching English in the classroom. And that's way code switching and code mixing often occur in their conversation.

Hymes (1875: 103) said that "Code Switching has become a common term for alternate use of two or more languages, varieties of language or even speech style". Moreover, English Switching is done by English teachers toward their students who still have a few vocabularies, especially in young english learner. Using English code switching will be appropriate in junior high school of Indonesia. The English Teachers in many junior high schools use Code Switching in-learning teaching prosess well consciously or unconsciously. Here, the researcher observed English Indonesian Code Switching Spoken by English Teacher in teaching learning process in the classroom. The researcher choose the context of sosiolingustics in Education field not in other public field because the researcher was interested to find and analyze English code switching in contex of Education by observing directly. From the statements above, the researcher conducted English Indonesian code switching spoken by the teacher in the first grade of MTsN Model Makassar. In this case, researcher analyzed it according to grammatical aspects, sosiolinguistic aspect and the fuction of using code switching in teaching learning process in the classroom. Therefore, the researcher conducted a research about "A Descriptive Analysis of English Indonesian Code Switching Spoken by the Teacher in the First Grade of MTsN Model Makassar".

\section{B. LITERAURE REVIEW}

The researcher takes the review of related literature from other graduating papers as the comparisons with this research.

The first is Falahiya, (2012) student of IAIN Sunan Ampel Surabaya, entitled Code Switching and Code Mixing as a Bridge in Speaking among First Year Student at MTs AlAmin Mojokerto. This study is the result of the observation to answer the question of what form of code switching and code mixing which are used by the first year student of Mts. AlAmin, and what is the first year students' response toward using code switching and code mixing at their speaking during English learning. This thesis conducts because she knows that in this modern era, there are many bilingual schools in Indonesia. This school requires their student to speak English and Arabic at their daily life. So from this study hopes that this study can give a contribution in sociolinguistics studies and additional knowledge in 
teaching speak English. This thesis uses qualitative method as the research design in this study. From the research, the writer finds there are four forms of code switching. They are code switching in the form of clause, sentence, tag, and exclamation. And two forms of code mixing, they are code mixing in the form of word and phrase. She finds that the using code switching and code mixing in the students speaking get a good response from student. They still need to use some code switching and code mixing as equivalence, as reiteration, and as conflictcontrol.

The second one is taken from Fariekhah (2012) student of IAIN Sunan Ampel Surabaya, entitle "Code Switching and Code Mixing Used by Teachers in SMPN 40 Surabaya". This research tells about phenomenon of code switching and code mixing which are used by teachers to their student in class activities. There are several reasons why researcher chooses English teacher as the subject of the study. First, is English teacher are those who are expert conversation especially in class activities. Second, the phenomenon of code switching and code mixing that happens in SMPN 40 Surabaya.The result of the research shows that there were some types of code switching and code mixing which were used by teacher in a class. They were code switching in the form of sentence, clause, and tag. On the code mixing, the researcher found in the form of word and phrase.

\section{Sociolinguistics}

According to Randal L. Whitman (1981:175), stated that sociolinguistics is concentrate on analyzing the diversity of language. There are many ways of describing the diversity of language: we can look at changes over geographical areas, at the various dialects of a language at special forms of language. And the sociolinguistics concerned not only with the description of such diversity but also with the analysis of how linguistic differences are related to sociological differences among individuals for example to diferences in socioeconomic class or ethnic groups.

According to Hudson (1980), he stated that sosiolinguistics is the study of language in relationship to society the use of a language has to appropriate to the context in which it is used.

While Holmes (1992:1) argue that "sociolinguistics is the study of the relationship between language, and society by identifying the social functions of language and the way it is used to convey social meaning". Thus it can be said that sociolinguistics is the study of what kind of language used in social context.

In addition, sociolinguistics includes every aspect of language which is related to social context or interaction, social class, education, immigration and bilingualism, nationalism, language planning, and varieties of language.

Wardhaugh (1986:13) also stated the term sociolinguistics is focused in investigating the relationships between language and society in order to be better understanding of the structure and society and of how languages function in communication. The same purpose 
in sociology of language is trying to find out how social structure can be better understood through the study of language.

\section{Speech Community}

Romaine (1992) stated that speech community is a group of people who do not necessarily share the same language, but share a set of norms and rules for the use of language. Then, I. Dewi .S adds people are social beings who belong to certain community. Each community has its own characteristics including its way of communication.

The term "speech marker" in speech community which is as a marker of social categories. This is important to discriminate. Social categorize like age, sex, ethnic, social class and situation will be easy to be marked in the base of cases. Then Giles, Schere, and Tylor said that such a categorization is fundamental to social organization.

Meanwhile Gumperz (1971: 101) used the term linguistic community rather than speech community. He proceeds linguistic community as follow: "Social group which may be either monolingual/multilingual, held together by frequency of social interaction pattern or set off from surrounding areas by weaknesses, in the line of communication.

\section{Code Switching}

Romaine (1992:110) said that Code switching can be defined as the use of more than one language, variety, or style by a speaker within an utterance or discourse, or between different interlocutors or situations.

This phenomenon can be observed in the following example:

- If you have an exam next week, șimdiden çalışmaya başlamalısin.

Code switching occurs mostly in bilingual communities. Speakers of more than one language are known for their ability to code switch or mix their language during their communication.

As Aranoff and Miller (2003:523) indicates that many linguists have stressed the point that switching between languages is a communicative option available to a bilingual member of o speech community on much the same basis as switching between styles or dialects is an option for the monolingual speakers.

\section{Approach of Code Switching}

According to Van Dulm (2007:9) the code switching study has two approaches: grammatical perspective and sociolinguistic perspective. Grammatical approach focuses on the structural aspects of code switching, the aim being to determine syntactic and morphological characteristics of code switching constructions. Meanwhile, sociolinguistic approach is concerned with the role of social factor in the occurrence of code switching, the aim being to determine pattern of occurrence of code switching and how these may be affected by social factors such as context and speaker ${ }^{\text {re }}$ role relationships.

According to Van Dulm (2007), he stated that in grammatical aspect of code 
Nur Aliyah Nur \& Fitriyani, A Descriptive Analysis of English Indonesian Code Switching Spoken ...

switching. There are three types of code switching

1. In Grammatical Aspect o Code Switching

a. Extrasentential/tag switching

b. Intersentential code switching

c. intra word switching

2. In Sociolinguistic Aspect of Code Switching

a. Metaphorical Switching

b. Situational switching

3. The Function of Code Switching (Phatic function)

Reason for Code Switching

There are a number of reasons for bilingual or multilingual person to switch or mix their languages. Those are:

a. Talking about a particular topic

b. Quoting somebody else

c. Being emphatic about something (express solidarity)

d. Interjection (inserting sentence fillers or sentence connectors)

e. Repetition used for clarification

f. Because of real lexical need

The most common reason for bilingual/multilingual person to switch or mix their languages is due to the lack of equivalent lexicon in the languages.

\section{RESEARCH METHOD}

The researcher presents the research method which is formulated into 7 parts. They are methodology approach, research setting, research subject, research time, data source, research instrument, procedure of collecting data, and data analysis technique.

\section{Methodology approach}

In this research, the researcher used a qualitative research. The qualitative research was used to develop the concept of sensitivity to the problems faced, explained the realities associated with the search of a grounded theory. The descriptive study used to seek a collection of instances from the data in the hope of the issue of the problems occurred.

Place Setting

This research was conducted in MTsN Model Makassar which was located in Jl. Andi Pangeran Pettarani No 1A Makassar. It was very good location and easily to find it.

Research subject

The subject of this research was one of the English Teacher in the first grade of MTsN Model Makassar, who teach in the VII.11 Class. 


\section{Research time}

This research was conducted in August 2015. It was conducted for two meetings for one class, started from the second weeks of August to the last week of August.

Data Source

The data was taken from English teacher of MTsN Model makassar who teachs in the first grade of VII 11 class that consists of one teacher.

\section{Research Instrument}

Observation : In this study, the researcher used two instruments. They were observation and recording note. Observation used in this research was non participant observation.

Recording and Note : Recording and note also made the researcher collect the data by using recorder like HP to record what the teacher conveyed in English teaching learning process.

\section{Collecting data Prosedure}

In collecting data there were some steps that conducted by the researcher. Those steps were presented as follows:

1. The researcher came to the class of VII.11 in MTsN Model Makassar and listened what the teacher conveyed.

2. The researcher wrote the code switching spoken by teacher and recorded what teacher said by using HP (hand phone).

3. The researcher also collected the data from field note.

4. The researcher listened the recording from HP and wrote the conversation during teaching learning process.

5. The researcher listened to the data that had been collected from recording by using HP. And the researcher classified the data based on the types of code switching.

\section{Data Analysis Technique}

In this chapter, the researcher used the qualitative method which empasized the study of the interaction that happend around the language that was used by the teacher who teach in VII.11 class in MTsN Model Makassar. The researcher analyzed the data started from the researcher collected the data from daily convertasion that happened in teaching learning process.

\section{FINDINGS AND DISCUSSIONS}

\section{Findings}

In this chapter, the researcher presents the data that have been collected from the observation before. Here the researcher answers the problem statements that were stated previously. They are about code switching that is spoken by English teacher process in the 
first grade of MTsN Model Makassar that involves types of code switching in Grammatical aspect, sosiolinguistic aspect, and the function of code switching that was spoken. In the analysis below, the researcher uses code in the data of conversation like $\mathbf{T}=$ teacher. $\mathbf{S}=$ students. The indonesian (italic). The utterence in which any switching, $\underline{\mathbf{B o l d}}=$ the poin of switching which become the categories. According to research question, the researcher presents finding such as:

Table Presentation

\begin{tabular}{|c|c|c|c|c|}
\hline No. & Categories & $\begin{array}{l}\text { Code } \\
\text { Switching }\end{array}$ & $\begin{array}{l}\text { Category of } \\
\text { Code } \\
\text { Switching }\end{array}$ & Utterences \\
\hline \multirow[t]{3}{*}{1} & $\begin{array}{l}\text { Grammatical } \\
\text { aspect of } \\
\text { code } \\
\text { switchiing }\end{array}$ & $\begin{array}{l}\text { Extrasential } \\
/ \text { tag code } \\
\text { switching }\end{array}$ & $\begin{array}{l}\text { English tag } \\
\text { switching }\end{array}$ & $\begin{array}{l}\text { Okay Silahkan buka halaman } \\
20 ! \\
\text { (Okay, please open page 20!) } \\
\text { So, Kalau minggu depan } \\
\text { belum membawa (kamus) } \\
\text { jangan masuk kelas! } \\
\text { (So, for the next week who } \\
\text { does not bring dictionary, dont } \\
\text { take an English class!) } \\
\text { well, ibu panggil namanya } \\
\text { (well, I call her name.) } \\
\text { kalau sudah selesai, ibu panggil } \\
\text { one by one } \\
\text { (if you have finished, I willcall } \\
\text { you one by one }\end{array}$ \\
\hline & & & $\begin{array}{l}\text { Indonesia tag } \\
\text { switching }\end{array}$ & $\begin{array}{l}\text { What do you want to ask, } \\
\text { silahkan! } \\
\text { ( What do you want to ask, go } \\
\text { a head!) } \\
\text { Bagaimana I call your nick } \\
\text { name? } \\
\text { (howcan I call your } \\
\text { nickname?). } \\
\text { And you, come forward . Ayo! } \\
\text { ( and you, come forward. } \\
\text { Come on!) }\end{array}$ \\
\hline & & $\begin{array}{l}\text { Intersentential } \\
\text { switching }\end{array}$ & $\begin{array}{l}\text { English } \\
\text { intersentential } \\
\text { Switching }\end{array}$ & $\begin{array}{l}\text { How about your dictionary? } \\
\text { Siapa yang tidak bawa? } \\
\text { (How about your dictionary? } \\
\text { Who does not bring?). } \\
\text { Many of your friends have the } \\
\text { same hobbies. Jadi kalau } \\
\text { ingin pergi nyanyi, ajak } \\
\text { teman teman yang lain! } \\
\text { ( so, many of your friends have } \\
\text { the same hobbies. So, if you }\end{array}$ \\
\hline
\end{tabular}




\begin{tabular}{|c|c|c|c|c|}
\hline & & & & $\begin{array}{l}\text { want to go singing, invite } \\
\text { your other friends!). }\end{array}$ \\
\hline & & & $\begin{array}{l}\text { Indonesia } \\
\text { Intersentential } \\
\text { Switching }\end{array}$ & $\begin{array}{l}\text { Ada yang lain? There may be } \\
\text { other version } \\
\text { (Others? there may be other } \\
\text { version). } \\
\text { Kalian punya tugas untuk } \\
\text { pertemuan selanjutnya. You } \\
\text { have to make the short } \\
\text { dialogue. } \\
\text { (you have the task } \\
\text { for the next meeting. You } \\
\text { have to make the short } \\
\text { dialogue!) }\end{array}$ \\
\hline & & $\begin{array}{l}\text { Intra Word } \\
\text { Switching }\end{array}$ & & $\begin{array}{l}\text { Di arraged! } \\
\text { (Tobe arranged!) }\end{array}$ \\
\hline 2 & $\begin{array}{l}\text { Sosiolinguistic } \\
\text { aspect of code } \\
\text { switching }\end{array}$ & $\begin{array}{l}\text { Metaphorical } \\
\text { Switching }\end{array}$ & & $\begin{array}{l}\text { the teacher give funhished for } \\
\text { one of the students, and } \\
\text { sheinvite him to introduce his } \\
\text { self in front of the class) } \\
\text { T: baiklah Reza, bisakah kamu } \\
\text { memperkenalkan diri didepan } \\
\text { teman teman kamu, atau } \\
\text { menyanyikan sebuah lagu untuk } \\
\text { kam? } \\
\text { (ok well, Reza can you } \\
\text { introduce your self? And } \\
\text { after that, you have to } \\
\text { singing a song for us) } \\
\mathrm{S}: \text { saya malu buu } \\
\text { (I am shy mam) } \\
\text { T: jangan malu malu. Makanya } \\
\text { kalau ibu menjelaskan, tolong } \\
\text { diperhatian. } \\
\text { (dont be shy. In others } \\
\text { time, if I am explaining, please } \\
\text { pay an attention) } \\
\mathrm{S}: \text { iya buu. Maaf } \\
\text { (yes, Iam sorry mom, while the } \\
\text { other students lauhged saw } \\
\text { Reza's expression } \\
\mathrm{S}: \text { hello friends, my name is Zabresa } \\
\text { Ramdani, my hobbies are } \\
\text { adventure and find some } \\
\text { beautiful places untuk refreshing } \\
\text { such as climbing a mountain } \\
\text { and swimming in the beach. }\end{array}$ \\
\hline
\end{tabular}




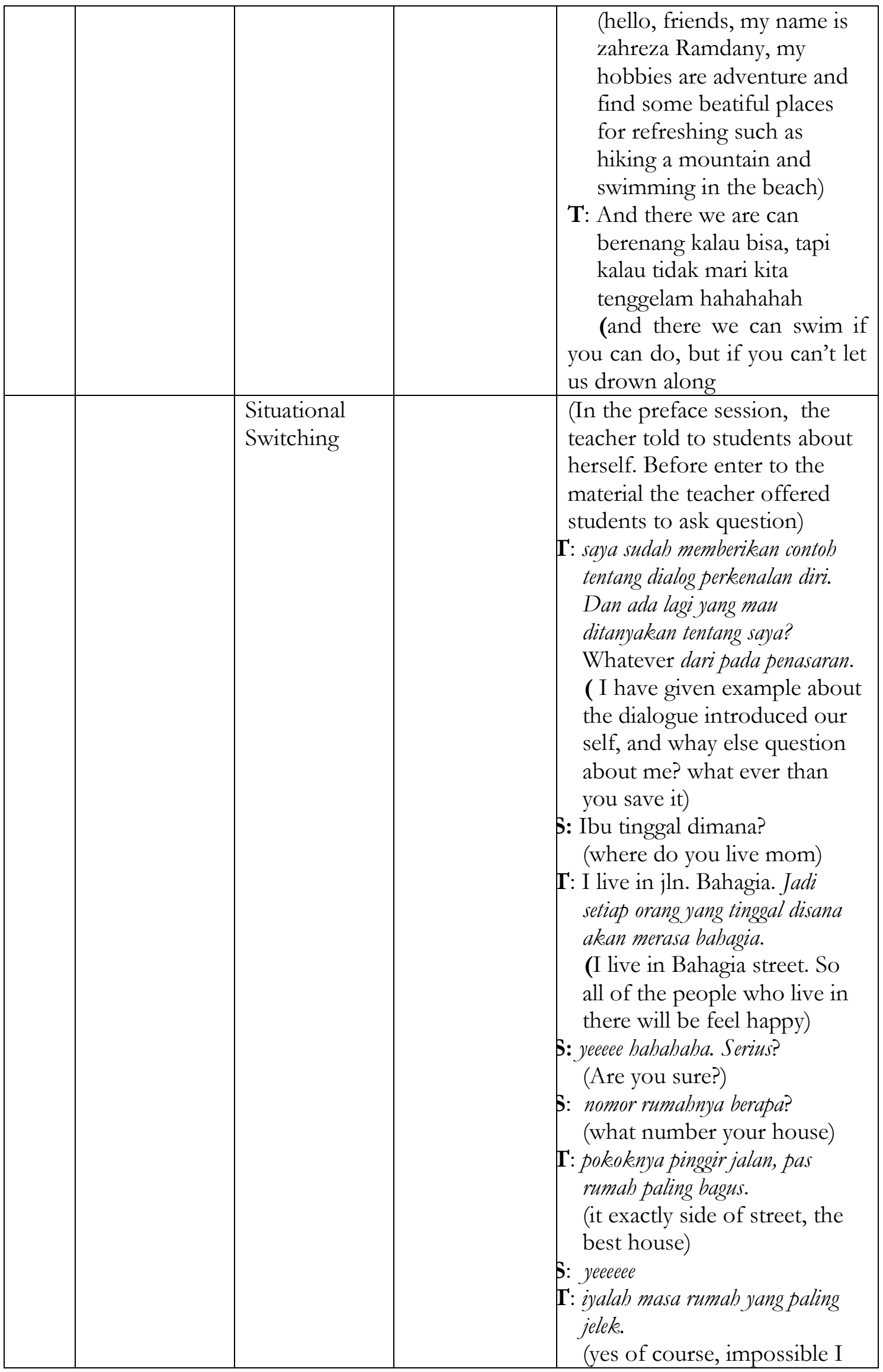




\begin{tabular}{|c|c|c|c|}
\hline & & & $\begin{array}{l}\text { want say the worst house) } \\
\text { 5: (laught) } \\
\text { I: Okay, enouhg? Saya kasi } \\
\text { bebrapa waktu untuk memulai } \\
\text { kembali pembelajaran hari ini } \\
\text { (okay, enouhg? I give some } \\
\text { time to begin our study } \\
\text { today) }\end{array}$ \\
\hline 3 & $\begin{array}{l}\text { Function of } \\
\text { code } \\
\text { Switching }\end{array}$ & $\begin{array}{l}\text { Phatic } \\
\text { function }\end{array}$ & $\begin{array}{l}\text { in opening class) } \\
\text { T:Assalamualaikum } \\
\text { S:waalaikumssalam wr.wb } \\
\text { T: are you okay? } \\
\text { S: yes } \\
\text { T: how are you? } \\
\text { S: I'm fine. And you? } \\
\text { T:I'm fine. But capek. If } \\
\text { you're still noise and laugh. } \\
\text { Okay but study must go on. } \\
\text { (I'm fine. But I'm tired If } \\
\text { you're still noise. Okay but } \\
\text { study must go on). }\end{array}$ \\
\hline
\end{tabular}

Discussion

a. The Grammatical aspect of Code Switching

Hamers and Blanc (2000:259), said Extrasentential code switching in volves attaching a tag from one language to an utterance entirely in the other language. Here, the writer will group tag-switching into two categories they are English tag switching and Indonesian tag switching:

English tag switching here, means the tag is in English and switch or insert to/from Indonesia utterance. The English tag that is spoken involves the word "Okay", "So", "well", “one by one".

The tag switching by the word "okay" occurs in the utterance (in the opening classroom, the teacher asked the students before star of the learning process)

T: Okay semuanya sudah siap belajar?

(okay students, are you ready to study?)

The tag switching by "so" also occurs in the conversation like:

(the teacher asks the completeness of the book to the students before star of the learning process in the classrom)

T: Siapa yang tidak membawa kamus? So, kalau minggu depan tidakmembawa kamus, jangan masuk kelas ibu!

T: who does not bring dictionary? So, for the next week who does not bring, dont go to my 
Nur Aliyah Nur \& Fitriyani, A Descriptive Analysis of English Indonesian Code Switching Spoken...

class!

(the teacher invites the student in front of the class to do convertation about sel introduction)

T: well, ibu panggil untuk anik memperkenalkan diri didepan kelas.

T: Well, I call your name come forward to introduce your personality about your name, address, and your hobby)

Indonesia Tag switching means the tag is in Indonesian than switch or insert to/from English utterance. The Indonesian tag switching in this research involves "silahkan, ayo, and the other example above.

(the teacher gave a chance for the student to ask about the related materials)

T: What do you want to ask? Silahkan!

T: What do you want to aks? Go ahead!

Intersentential code switching involves switching at sentential boundaries, where one clause or sentence is in one language and the next clause or sentence is in the other Mac Swan (1999:1). It same with what Mc Atrthur said, inter sentential switching, in which a change of language occurs at a clause or sentence boundary, where aech clause or sentence is in one language or the other. There are two tag in intersentential switching they are English indonesia intersentential switching and Indonesia English intersentential Siwtching.

In this category, English intersentential switching is begun from English to Indonesia Utterence such as:

(the teacher asks the students to learn equipment before starting the learning process)

T: How about your dictionary? Siapa yang tidak bawa?

T: (How about yourdictionary? Who does not bring?)

T: I wanna look your note book. Apakah ada catatan pertemuan sebelumnya?

T: ( I want to look your note book. Is there a note for the previous meeting?)

Indonesia English intersentential switching. In this category, Indonesia intersentential switching begun from Indonesia to English utterence. For example

(students were asked to do their assignment in front of class to do self introduction convertation, and the teacher corrected them)

T: ada yang lain? There may be other version?

T: any others? There may be other version?

Intra word switching. According to Mc Arthur (1998), intra word in which a change occurs within a word boundary. There is one intra word switching which occurs in English word and has prefix "di" like utterences.

(after teacher gave explanation about "How to Introduce our Self" she gave assignment to students).

T: Ok, Kerjakan dengan teman sebangkumu dengan membuat dialogue tentang percakapan perkenalan diri. Disusun sesenai dengan urutannya. 
T: Ok, do it along your partner by making dialogue about conversation-self introduction. Arangged based on the order.

\section{b. The Sosiolinguistic Aspects of Code Switching}

Blom and Gumperz (1972), have the different types of code switching in the sociolinguistic aspect of code switching namely: situational code switching and metaphorical code switching.

\section{Situational code switching}

In this research, it is found situational switching in learning teaching process.

\section{Metaphorical Switching}

According to Li Wei john Edward (1994:156), Metaphorical switching referred to change in the speaker's language choice when the situational remained the same. For some people switch in this case was thought to convey special communicative intent. In learning teaching process of MTsN Model Makassar is found some methaporical switching utterences such as presented obove

\section{c. The Function of Code Switching}

Actually, there are many function of code switching according to Appel and Muysken. But for this research, the researcher only discussed about phatic function such as presented above:

The utterence of "capek" as the signal to switch to the Indonesia language in which the previous conversation uses English. So the utterence "capek" show phatic function which is used as a signal to begin conversation in Indonesia language.

Phatic function is used to show a change in tone and emphasize parts of a conversation that are of importance. Appel and Musyken (1987: 29-30) also said the phatic function is orientation on communication it self, by using conventionalized opening, closing, and ways to signal turn-taking, also by using language form that identify the group in within which interaction is taking place.

\section{CONCLUSION}

Based on the problem statements and research analysis, the researcher concludes as follow:

The grammatical aspect of code switching in English-Indonesia code switching spoken by the teacher in MTsN Model Makassar were extrasentential switching (tag switching), intersentential switching, and intra word switching. The extrasentential switching (tag switching) was divided into English tag like (okay, so, true, and, one by one, well, please, any question) and Indonesian tag switching involves (iya, silahkan, ayo, kamu, bagaimana). Intersentential switching English-Indonesia and Indonesia-English. Intra word switching, with enter the word "di" to english utterence "arange" to be di-arrange! The sociolinguistic aspect of 
Nur Aliyah Nur \& Fitriyani, A Descriptive Analysis of English Indonesian Code Switching Spoken ...

code switching in English-Indonesia code switching spoken by the teacher in the fist grade MTsN Model Makassar in VII.11 class were situational and metaphorical code switching. The function of code switching in English-Indonesia code switching spoken by the teacher in the first grade of MTsN Model Makassar was a phatic function.

\section{E. SUGGESTION}

From this research, the researcher gives suggestion to the reader such as For the teacher Code switching is one way to make easier in study language so it will useful for teacher to be used for conveying material and communication with their students as a drill of listening and speaking for the students in teaching-learning process. Than For the students, Code switching can be used to make easier in conversation, especially in using foreign language so it is as a medium of drill. And For the readers, They can understand code switching and can be applied in their daily life and can enrich and develop the sociolinguistics study.

\section{BIBLIOGRAPHY}

Auer, Peter. Code Switching in Conversation. London: Routledge, 1998.

Alfiyah, Nur. Code Switching and Code Mixing Used By Teachers In SMPN 40Surabaya. Skripsi. Surabaya: IAIN Sunan Ampel, 2011.

Appel, R. \& Muysken P. Language Contact and Bilingualism. Amsterdam: University Press, 2006. Aranoff, M. And Rees-Miller. J, The handbook of Linguistics. Blackwell publisher: Oxford. 2003 Arikunto, Suharsimi. Prosedure Penelitian: Suatu Pendekatan Praktik. Jakarta,2013

Arthur, Tom Mc. Code Mixing and Code Switching: Concise Oxford Compaining to the English Language.Bilingual Conversation. Journal of Pragmatics 33(12),1901-1925

Bunging, Burhan. Metodologi Penelitian Qualitative. Jakarta, 2011

Chaer, Abdul and Leonie Agustina. Sosiolinguistik. Jakarta: PT Rineka Cipta, 2004.

Chomsky, Noam. Aspect of the theory of Syntax. Cambridge, MA: MIT press1965

Crystal D, The Cambridge Encyclopedia of Language. Cambridge University. Press: Cambridge 1987

Emzir. Analisis Data:Metodologi Penelitian Kualitatif. Jakarta Utara: PT. Raja Grafindo Persada, 2011.

Fariekhah. Code Switching and Code Mixing used by teacher in SMPN 40 Surabaya. Skirpsi student of IAIN Sunana Ampel Surabaya 2012

Falahiyah. Code Switching and Code Mixing as a bridge in Speakig among first year student at MTs Al Amin Mojokerto. Skripsi at IAIN Sunan Ampel Surabaya. 2012

Hadeli. Metode Penelitian Pendidikan. Jakarta: Quantum Teaching 2006.

Holmes, Janet. An Introduction to Sosiolinguistic. United State of America: Longman, 1992.http://www.crisaps.org/newsletter/summer2009(10 july 2015). 
—March. Code Switching in ConversationLanguage, Interaction and identity http://www.ude.es/dep/1X/cac/c-s/pres.html. 1998. ( 6 August 2015).

Nina. Code Switching and Code Mixing. Jakarta 2008 <http:/just-dropbyblogspot.com/2008/03/code switching.-and-codemixing.html>.(March 2008).

Ninaz. March. Code Switching and Code Mixing. Jakarta, 2008.

Rosyidi, Ajip. Bahasa Nusantara. Jakarta: PT. Dunia Pustaka Jaya, 1999.

Romaine, S. Bilingualism. Blackwell Publishers: Cambridge, 1992.

Setyaningsih, Nina. Code Switching in The Home-office Domain (A Case Study of the Daily Conversations among Workers at Salemba Emban PatriaSemarang). Semarang: Diponegoro University, 2005.

Skiba, R. Code Switching as a Countenance of Language Interference. The Internet TESL Journal. Vol. III. No: 10. (1997) < ttp://iteslj.org/Articles/Skiba-CodeSwitching.html (6 August 2015).

Sumarsono. Sosiolinguistik. Yogyakarta: Pustaka Pelajar, 2002.

Wardhaugh, Ronald. An Introduction to Sociolinguistics; Second Edition. Cambridge USA: Blackwell, 1986.

Wardhaugh, Ronald. An Introduction to Sociolinguistics. Oxford: Basil Blackwell, 1992.

Wei, Li.The "Way" and "How" Questions in the Analysis of Conversational Code Switching. In Code Switching Conversation, Language Interaction \& Identity, London: Routledge, 1986.

Whitman, Randal L. An Introduction to Lingustics. Canada: Simultaneously. 1981.

Wijaya, I Dewa Putu \& Muhammad Rohmadi. Sosiolinguistik; Kajian Teori dan Analisis. Yogyakarta: Pustaka Pelajar, 2006. 